\title{
Attitude of Youths and Young Graduates towards Entrepreneurial Skill Acquisition in Abeokuta, Ogun State: Issues and Prospects
}

\section{Odunayo Salau*}

Lecturer, Business Management Department, Covenant University, Nigeria

\begin{abstract}
This research was conducted in order to assess and evaluate the attitude of Youth and Young graduates towards entrepreneurial skill acquisition in Abeokuta town, Ogun state, South West, Nigeria. The study identified the specific needs of youths in entrepreneurship; attitude of the young graduates towards entrepreneurship skills and also identified the factors affecting entrepreneurial characteristics among the Youth/Young graduates. A structured questionnaire was used for the study. The questionnaire was distributed to participants at Muda Lawal Stadium, Abeokuta, Ogun state when they converged for immigration interview in March, 2014. Thus, the sample size used for the study comprised valid 400 respondents which represents $20 \%$ of the unemployed youths in attendance. The statistical tool for analyzing the data and interpretation was the chi-square (non-parametric) statistical technique and percentage counts. The study revealed that most of the Youths/Young graduates had little or no knowledge about entrepreneurship education and training from their respective tertiary institutions. Therefore, entrepreneurship training should be part of programmes of National Youth Service Corps (NYSC) in Nigeria to make the fresh graduate self-employed after a year mandatory programme to serve their father land. The National Universities Commission (NUC) should mandate all Tertiary Institutions in Nigeria to create Entrepreneurship development centre and put in place two compulsory courses on entrepreneurship for all undergraduate students' irrespective of their discipline. Governments at all levels can also support with funding schemes, tax policies through micro enterprises and the supply of needed infrastructures, business information and advices.
\end{abstract}

Keywords: Entrepreneurship development; Creativity; Capacity development; Unemployment; Poverty

\section{Introduction}

Entrepreneurship has become a fundamental aspect in promoting economic success, steadiness and wealth. The significance of entrepreneurship has contributed immensely in reducing the extent of unemployment and thereby promoting employment opportunities among the youth especially university graduates. The development and economic stability of every nation has been shaped and carved by men and women who have taken their destinies in their own hands by perceiving opportunities and risking their resources (money, machines, materials, men) in establishing and operating their own business [1]. This is collaborated by Adeboye and Olubela [2] that entrepreneurship is a systematic process of identifying needs and satisfying those needs with creative thinking and values with the aim of acquiring wealth and promoting the sense of self reliance, self determination, independence and life or personal satisfaction. The survival of every society (developed or developing) is a dependent factor on the level of entrepreneurial abilities undertaken. Amadasun adduced that countries with less attention to entrepreneurship are likely to be surrounded with the daunting problem of unemployment, poverty, oppression and undue exploitation from the owners of the means of production. Adediran [3] posited that unemployment problem which is on an alarming rate has become an atrocious phenomenon which has eaten deep into the fabrics of our economy. Researches indicated that people who are commonly affected by the syndrome are the economically active population such the youths particularly graduates from tertiary institutions, and also people who are retrenched as a result of economic recession, and sociocultural discrepancies.

In Nigeria today, the geometric progression and trend of the unemployed has revealed that young graduates from tertiary institutions do not the necessary entrepreneurial abilities, competencies, exposures values that will help them to adapt and integrate to the world of business. Okwuanaso [4] also argued that many graduates who tend to establish and be independent in their own little way often failed in the world of work and this can be associated to their little knowledge of what it takes to to be an entrepreneur. Yahya [5] added that the kind of skills acquired by the young graduates from various tertiary institutions has to a large extent influenced entrepreneurial abilities and which in turn adversely affect them in the world of business. A study by Okebukola [6] confirmed that most of the economically active populations (youths) in Nigeria are over dependent and oppressed by the bourgeoisies due to their insufficient funds, resources and low level of entrepreneurial skills. Though these problems have been associated with lack of accessibility to loan, poor infrastructural development/ facilities, inadequate funding by the government. All these are indicators to acquiring the necessary skills and competencies needed for proper adaptation and integration within the environment of competitive rivalry [7].

Timmons and Spinelli [8] also pointed out that attitude serves as a contributory factor in the life of a flourishing entrepreneur. The attitude an entrepreneur places on his business, will determine the level of his profit. As an entrepreneur continues to perceives and create opportunities, they are bound to face some contingencies and thereby provide means to overcome the challenges in order to attain and achieve a prime over and competitive edge. As Anerua and Obiazi

*Corresponding author: Lecturer, Business Management Department, Covenant University, Nigeria, Tel: +234 807771426; E-mail: odunayo.salau@ covenantuniversity.edu.ng

Received September 15, 2014; Accepted October 07, 2014; Published October 17,2014

Citation: Salau O (2014) Attitude of Youths and Young Graduates towards Entrepreneurial Skill Acquisition in Abeokuta, Ogun State: Issues and Prospects. Int J Econ Manag Sci 3: 192. doi: 10.4172/2162-6359.1000192

Copyright: () 2014 Salau O. This is an open-access article distributed under the terms of the Creative Commons Attribution License, which permits unrestricted use, distribution, and reproduction in any medium, provided the original author and source are credited. 
[9] pointed out that a successful entrepreneur must have core values, must be consistent, determined relentless and also not be weary by any circumstances. Invariably, the understanding of these attitudes will go a long way in determining and encouraging entrepreneurship within a particular country [10]. Sasaki [11] in his study adduced that if young graduates of today are better informed of the relevance and challenges of becoming self reliant and independence, they will not only choose being an entrepreneur as a profession but also complement their efforts in achieving competitive advantage and creating more wealth. As it could be inferred from above that not much research has been conducted on the relationship between all of these constructs and variables. A thorough understanding of 'how' and 'why' entrepreneurship or vocational skill acquisition is important for reducing unemployment among the young graduates from the tertiary institutions will help the youths in the selected state. It is to this end that this paper seeks to critically examine the attitude of youth and young graduate towards entrepreneurial skill acquisition and employment generation in Abeotuta, Ogun state.

\section{Statement of the Problem}

Studies indicate that Nigeria is beleaguered and overwhelmed with high levels of unemployment, crime rate and poverty. Though Government in collaboration with private investors has tried to encourage the practice of entrepreneurship but low progress has been made up to date. This can be associated to the attitude, low level of understanding and perceptions among the youth /young graduates towards entrepreneurship. There are several researches on entrepreneurship education, poverty, entrepreneurship diversity but only little studies we have on Entrepreneurial Skill Acquisition Programme through the Youths and young graduates in Ogun state.

Universities in Nigeria produces millions of graduates each year to the economic that is already overpopulated. Meanwhile, most fresh graduates prefer to get a white collar job after their youth service year. Experiences over the years have revealed that seventy percent of these graduates end up roaming about the street seeking for job that will earn them 'fat salaries'. On getting to the labour market they found that the otherwise is the case, they get more distracted and frustrated thereby developing any other means of making ends meet. This problem was noted by the government and its agencies and decided to introduce Entrepreneurial Skill Acquisition Programme through the NYSC body to serve as a training section for the young graduates during their stay in the orientation camp.

The study covered the following questions:

1. How can we identify the specific needs of youths in entrepreneurship?

2. How has the attitude of the young graduates towards entrepreneurship skills contributed to the problem of unemployment?

3. What are the factors affecting entrepreneurial characteristics among the young graduates in Abeokuta town, Ogun state.

4. What are the recommended policies set by the governments?

\section{Literature Review}

The concept of entrepreneurship has become the fundamental and valuable way to promote self-reliance and self-employment among young people. Several literatures have indicated that employment for young people can be created by exploiting an invention or more generally an untried technological methods of producing a new commodity or producing an old one in a new way through an active micro-enterprises. When the young people lack the basic entrepreneurial abilities, it therefore becomes difficult for them to succeed and triumph in the world of business Sasaki [11]. Literatures explained the concept of entrepreneurship from two major perspectives or school of thoughts. The first perspective focused on "creating opportunities" and the second perspective is called "innovation" [12]. Entrepreneurship is a dynamic process of adopting innovation to create new value in the market. Adeboye and Olubela [2] also see entrepreneurship as a dynamic way of perceiving opportunities and introducing changes, innovations and a new order. Obasan added that in entrepreneurship, the concept of innovation and newness should be seen as integral aspects. Therefore, the success of an entrepreneur lies on his ability to identify needs, create value and exploit innovations.

Kor, Mahoney and Michael [13] adduced that an entrepreneur is one who brings resources and other assets into combination that make their value greater than others. This definition uphold the fact that an entrepreneur is someone who create and produce needs or values in a new way. In making entrepreneurial decision, it is important to consider the role of risk taking and uncertainty. Timmons and Spinelli [8] posited that an entrepreneur is a person who is internally motivated to create something new with value by devoting the necessary time and effort and also with the enthusiasm for invention, discovery and creativity. Agada and Ekpa [14] collaborated that an entrepreneur is solely vested with the passion to create value and satisfy needs.

Creating value and exploiting innovation process is parallel to need for achievement $[15,16]$. Obazi also supported that Entrepreneurship primarily focuses on value creation and the exploitation of economic innovation. Murray added that incremental wealth of value creation cannot be strongly achieved without entrepreneurship education. Entrepreneurship education requires the devotion and intention to undertake risk, organization of socio-economic resources and acceptance of creative thinking [17]. These entrepreneurship skills are accompanied with individual's understanding of similar notions such as newness, organizing, wealth creation and risk taking and also the ability to successfully perform particular responsibilities [9]. Basically, it is worthy to reiterate that the significance of entrepreneurship skills cannot be quantified since the knowledge and skills acquired through entrepreneurship will assist the youths and young graduates to be independent, self-reliant or self-employed person and contribute immensely to the economic success of the society at large. Uloka and Ejinkonye [18] argued that when the young graduates and youths acquired the necessary skills and knowledge through entrepreneurship, that there is a greater chance to use the skills to create something new with value.

\section{The statistics on graduate unemployment in Nigeria}

According to the discussion paper by UN 2012 Annex Table and Population Reference Bureau (PRB) (2003-2013), dealing with youth unemployment in Nigeria, young people are disadvantaged in the labour market. The youth unemployment has escalated over the past five years (2009-2013) as a result of the economic downturn and decline. The following Figure 1 and Table 1 compare youth unemployment with the overall population in Nigeria

It is stated that the unemployment rate geometrically increased with an alarming rate since the year 2007 through 2013. The unemployment rate among the youths most especially the young graduates between 2003 through 2013 is with an average of $17.9 \%$ of the total population 
Citation: Salau O (2014) Attitude of Youths and Young Graduates towards Entrepreneurial Skill Acquisition in Abeokuta, Ogun State: Issues and Prospects. Int J Econ Manag Sci 3: 192. doi: 10.4172/2162-6359.1000192

Page 3 of 11

(UN 2012 Annex Table and Population Reference Bureau (PRB), 20032013).

\section{Research hypotheses}

As obtained in the reviewed literature above, we therefore proposed the following hypotheses:

$\mathrm{Ho}_{1}$ : There is a positive relationship between entrepreneurial skill acquisition and Youth/young graduates' employment generation.

$\mathrm{Ho}_{2}$ : Attitudes of the youths/young graduates towards entrepreneurship skills does not contribute to high level of unemployment.

\section{Research model}

This study will give attention to the attitude of youths and young graduates towards entrepreneurial skill acquisition in Abeokuta, ogun state. However as obtained in the literature reviewed above, we proposed the following model depicted in Figure 2.

\section{Research Methodology}

The study engaged in the use of both explanatory and survey research designs. The population of the study comprises the entire Youths and Young graduates in Abeokuta town, Ogun State. In view of the large size/population and in order to achieve the main objectives of the study, both the youths and young graduates were used as case study. Thus, the sample size used for the study comprised valid 400 respondents. The simple random sampling technique was used for effective gathering of data from Youths and Young graduates in Abeokuta town, Ogun State. The use of questionnaires was employed to gather necessary and relevant data from respondents. The questionnaire was distributed to participants at Muda Lawal Stadium, Abeokuta, Ogun state when they converged for immigration interview in March, 2014. The questionnaire was divided into two sections 1 and 2. The first section addressed the personal data of the individual such as Age, Sex, Marital Status, Educational Status e.t.c. and while the other section examined the variable being investigated. The statistical tool for analyzing the data and interpretation was the chi-square (nonparametric) statistical technique and percentage counts.

\section{Data analysis and presentation of result}

In analyzing the data collected, the use of tables were adopted. The primary source of data collected was used. In the Table 2 above, number one shows sex of the respondents, it was revealed that, $45 \%$ are female while $55 \%$ are male. The second number of the table shows the age group of the respondents that $27 \%$ are below 25 years, $48 \%$ are between $25-30$ years, as $25 \%$ are between the age of 30 years and above. The third number depicts the percentage of marital status of the respondents that $76.0 \%$ are single while $24.0 \%$ are married. The fourth number depicts the percentage of educational qualification of the respondents; it shows that $13 \%$ are OND/NCE holders, $25.0 \%$ are HND holders while $53.0 \%$ are B.Sc holder and only $9.0 \%$ are holders of M.Sc/M.BA and Others. The table above revealed that majority of the respondents is B.Sc holders with a percentage of $53.0 \%$.

\section{Analysis of the research hypothesis}

$\mathrm{Ho}_{1}$ : There is no positive relationship between entrepreneurial skill acquisition and Youth/ Young graduates' employment generation in Ogun state.

Hypothesis 1: This shall be tested by the use of respondent's responses to question 22 (Tables 3 and 4 ).
However, from the first hypothesis tested, it was discovered that;

$\mathrm{X}^{2}$ (i.e Chi-square calculated) is equal to 63.980 , while the Chisquare tabulated $\mathrm{X}^{2} \mathrm{t}$ is equal to 5.991 , meaning that the $\mathrm{X}_{\mathrm{C}}^{2}>\mathrm{X}^{2} \mathrm{t}$. The interpretation of this finding revealed that there was positive relationship between entrepreneurial skill acquisition and Youth/ Young graduates' employment generation in Ogun state. Statistically, we therefore accept the Alternative hypothesis (HI) and reject the null hypothesis (Ho).

\section{Test of Hypothesis II}

The second Hypothesis to be tested here states thus:

$\mathrm{Ho}_{2}$ : Attitudes of the youths/young graduates towards entrepreneurship skills does not contribute to high level of unemployment.

Hypothesis 2: This shall be tested by the use of respondents' responses to question 23 (Tables 5 and 6).

However, from the first hypothesis tested, it was discovered that; $\mathrm{X}_{\mathrm{C}}^{2}$ (i.e Chi-square calculated) is equal to 30.320 , while the Chisquare tabulated $X^{2} t$ is equal to 5.991 , meaning that the $\mathrm{X}_{\mathrm{C}}{ }_{\mathrm{C}}>\mathrm{X}^{2} \mathrm{t}$. The interpretation of this finding is that, the Attitudes of the youths/young graduates towards entrepreneurship skills has greatly contributed to high level of unemployment. Statistically, we therefore accept the Alternative hypothesis (HI) and reject the null hypothesis (Ho).

\section{Managerial Implications, Conclusion and Recommendations}

The first objective examined the specific needs of youth corps in

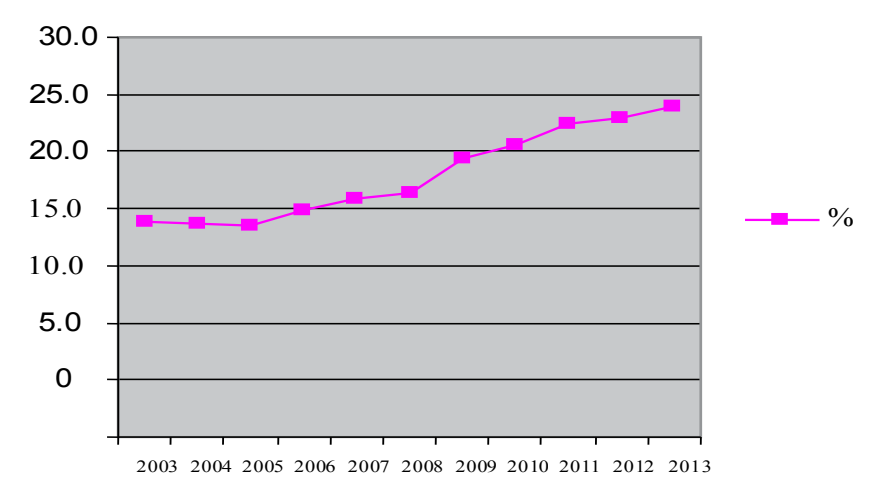

Figure 1: Unemployment rate of young graduates and Nigeria population, Source: UN 2012 Annex Table and Population Reference Bureau (PRB) (20032013)

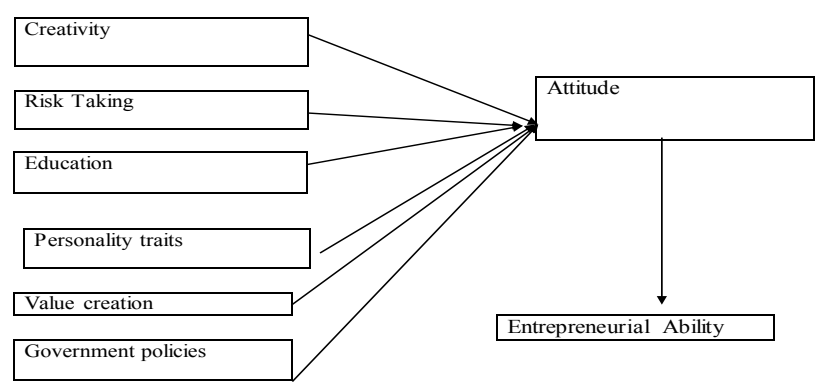

Figure 2: Proposed Study Model, Source: A model proposed by the authors 
Citation: Salau O (2014) Attitude of Youths and Young Graduates towards Entrepreneurial Skill Acquisition in Abeokuta, Ogun State: Issues and Prospects. Int J Econ Manag Sci 3: 192. doi: 10.4172/2162-6359.1000192

Page 4 of 11

\begin{tabular}{|l|c|c|c|}
\hline $\mathbf{s} / \mathbf{n}$ & Year(s) & $\begin{array}{c}\text { Youth Unemployment rate in } \\
\text { Nigeria (in \%) }\end{array}$ & $\begin{array}{c}\text { Population } \\
\text { (in millions) }\end{array}$ \\
\hline $\mathbf{1}$ & 2003 & 14.8 & 133.9 \\
\hline 2 & 2004 & 13.4 & 137.3 \\
\hline 3 & 2005 & 11.9 & 131.5 \\
\hline 4 & 2006 & 13.7 & 134.5 \\
\hline 5 & 2007 & 14.6 & 144.4 \\
\hline 6 & 2008 & 14.9 & 148.1 \\
\hline $\mathbf{7}$ & 2009 & 19.7 & 152.6 \\
\hline 8 & 2010 & 21.1 & 158.3 \\
\hline 9 & 2011 & 23.9 & 162.3 \\
\hline 10 & 2012 & 23.9 & 170.1 \\
\hline 11 & 2013 & 24.9 & 173.6 \\
\hline & Average of 2003-2013 & $\mathbf{1 7 . 9}$ & \\
\hline
\end{tabular}

Table 1: Brief analysis on Unemployment rate of young graduates and Nigeria population

\begin{tabular}{|c|c|c|c|c|}
\hline$S / N$ & & & Frequency & Percent \\
\hline 1 & $\begin{array}{ll}\text { Sex; } & \text { Fem } \\
& \text { Mal } \\
\text { Total } & \end{array}$ & & $\begin{array}{l}180 \\
220 \\
400\end{array}$ & $\begin{array}{c}45.0 \\
55.0 \\
100.0\end{array}$ \\
\hline 2 & $\begin{array}{l}\text { Age Group: } \\
\text { Total }\end{array}$ & $\begin{array}{l}\text { Below } 25 \text { years } \\
25-30 \text { years } \\
30 \text { years and above }\end{array}$ & $\begin{array}{l}108 \\
192 \\
100 \\
400\end{array}$ & $\begin{array}{c}27.0 \\
48.0 \\
25.0 \\
100.0\end{array}$ \\
\hline 3 & $\begin{array}{l}\text { Marital Status } \\
\text { Total }\end{array}$ & $\begin{array}{l}\text { Single } \\
\text { Married }\end{array}$ & $\begin{array}{r}304 \\
96 \\
400\end{array}$ & $\begin{array}{c}76.0 \\
24.0 \\
100.0\end{array}$ \\
\hline 4 & $\begin{array}{l}\text { Educational Q } \\
\text { Total }\end{array}$ & $\begin{array}{l}\text { Qualification: } \\
\text { OND/NCE } \\
\text { HND } \\
\text { B.Sc } \\
\text { M.Sc/M.BA \& Others }\end{array}$ & $\begin{array}{r}51 \\
\\
101 \\
210 \\
38 \\
400\end{array}$ & $\begin{array}{r}13.0 \\
25.0 \\
53.0 \\
9.0 \\
100.0\end{array}$ \\
\hline
\end{tabular}

Table 2: Analysis of Socio-Demographic Characteristics of Respondents, Sources: Authors' survey

\begin{tabular}{|c|c|c|c|}
\hline & Observed N & Expected N & Residual \\
\hline Yes & 284 & 133.3 & 150.7 \\
\hline No & 64 & 133.3 & -69.3 \\
\hline Undecided & 52 & 133.3 & -81.3 \\
\hline Total & 400 & & \\
\hline
\end{tabular}

Table 3: Hypothesis 1

\begin{tabular}{|c|c|}
\hline & Hypothesis 1 \\
\hline Chi-Square & $63.980 \mathrm{a}$ \\
\hline Df & 2 \\
\hline Asymp. Sig. & .000 \\
\hline
\end{tabular}

aZero cells $(.0 \%)$ have expected frequencies less than 5 . The minimum expected cell frequency is 133.3 .

Table 4: Test Statistics

entrepreneurship. The study revealed that most of the Youths/ young graduates had little or no knowledge about entrepreneurship education and training in their undergraduate days. The study revealed that motivational talks, raising funds, training and care are the needs of the youth corps in entrepreneurship and skill acquisition. It was found that entrepreneurial activities have specific needs divergent from the general population, some needs in these two groups are identical, such as financing while some are lack of training and knowledge about entrepreneurship but each area presents its own unique challenges. For example, youth do not often have collateral for a loan, making it difficult to obtain financing from an official institution. It was also stated that youth entrepreneurship would be virtually impossible without the existence of motivational factors like adequate training and education for youth (Kor, Mahoney and Michael [13]. According to Youth Business International (YBI) and The Princes Scottish Youth Business Trust by Morris [15], both found that 20 percent of youth have the potential to become entrepreneurs but has no knowledge.

The second objective examined the attitude of the young graduates towards entrepreneurship skills. The findings revealed that when students are not equipped with the necessary entrepreneurial abilities and attitudes, it affects their competence and make them incapable of surviving in the corporate world. Okebukola [6] also confirmed that the attitude and values young graduates in Nigeria places on entrepreneurship education are atrocious and this makes them to be dependent and not self-reliant.

The third objective identified the aims to identify the factors affecting entrepreneurial characteristics among the young graduates. The study unveiled that lack of personal savings and resources, lack of knowledge and lending, inability to take risk, poor entrepreneurial and management skills, constitute some of the factors affecting entrepreneurial characteristics among the Youths/ young graduates. It was discovered that almost all the Tertiary Institutions in Ogun state, Nigeria have no curriculum standard for entrepreneurship education and this makes it difficult for the youths to have both theoretical basis and practical knowledge for developing their entrepreneurial abilities and skills. Literature support that Entrepreneur development takes place within a framework of forces that constitute the system environment, which are either external or internal. A critical issue in the entrepreneurial development and growth is firm's ability to adapt to its strategies to a rapidly changing system environment to which the entrepreneurs' role is critical to the success or failure of such firm. For the entrepreneur to be successful, he must be able to identify and find a useful niche within the large environment where it takes its risk, make strategic business plan and take/implement decisions. Entrepreneurs must always identify needs, explore the changes and create values that will foster the attainment of competitive advantage [8].

Based on the examination of the recommended policies, the study observed that raising funds, lending and training and the use of technological innovations are the recommendation policies that can be used to promote entrepreneur among the youth/ young graduates. This

\begin{tabular}{|c|c|c|c|}
\hline & Observed N & Expected N & Residual \\
\hline Yes & 232 & 133.3 & 98.7 \\
\hline No & 112 & 133.3 & -21.3 \\
\hline Undecided & 56 & 133.3 & -77.3 \\
\hline Total & 400 & & \\
\hline
\end{tabular}

Table 5: Hypothesis 2

\begin{tabular}{|c|c|}
\hline & Hypothesis 2 \\
\hline Chi-Square & $30.320 \mathrm{a}$ \\
\hline Df & 2 \\
\hline Asymp. Sig. & .000 \\
\hline
\end{tabular}

a Zero cells $(0 \%)$ have expected frequencies less than 5 . The minimum expected cell frequency is 133.3 .

Table 6: Test Statistics 
Citation: Salau O (2014) Attitude of Youths and Young Graduates towards Entrepreneurial Skill Acquisition in Abeokuta, Ogun State: Issues and Prospects. Int J Econ Manag Sci 3: 192. doi: 10.4172/2162-6359.1000192

is therefore supported by the literature that entrepreneurial training and education encourages Nigeria to become jobs creator rather than job seekers. It also equips them with skills for constant improvement and innovations in their undertaken. The study revealed that a viable government policies and environmental policies are the policies needed not only to be formulated but implemented in enhancing youth entrepreneurial skills. Governments at all levels could intervene in providing financial back to the youths through micro enterprises and the supply of needed technological and business information and advices. Entrepreneurship training should be part of programmes of National Youth Service Corps (NYSC) in Nigeria to make the fresh graduate self-employed after a year mandatory programme to serve their father land. The National Universities Commission (NUC) should mandate all Universities in Nigeria to create Entrepreneurship development centre and put in place two compulsory courses on entrepreneurship for all undergraduate students' irrespective of their discipline. The same thing should be done for the Polytechnics and Colleges of Education.

\section{References}

1. Kuye OL, Oghojafor BEA, Sulaimon AA, Okonji PS (2009) Empowering Nigerian Youths for National Economic Development: The Role of Entrepreneurship education.

2. Adeboye B, Olubela A (2009) Entrepreneurship. Lagos. Ifunaya Prints Ltd.

3. Adediran OA (2004) Reducing Unemployment through Sustainable Business Education. J. Bus. Admin. Manage. (JOBAM) 2 (2): Ede. Federal Polytechnic.

4. Okwuanaso SI (1992) Office education and self reliance: A need for up-to-date curriculum. Business Education Journal, 11(2):1010-1015.

5. Yahya HV (2007) Entrepreneurship education. Vanguard Education Weekly, 22(37).
6. Okebukola P (2005) Quality assurance in Teacher education. A publication of the committee of Deans of Education in Nigerian Universities.

7. Herrington M, Kew J, Kew P (2009) Tracking entrepreneurship in South Africa: A GEM perspective. Cape Town: University of Cape Town.

8. Timmons JA, Spinelli S (2009) New venture creation entrepreneurship for the 21st Century. 8th ed. Boston, MA: McGraw-Hill.

9. Anerua FA, Obiazi AE (2009) Entrepreneurship education in home economics: problems and prospects. A paper presented at the annual national conference of association for encouraging qualitative education held at Federal College of Education, Nassarawa, 11 th to 15 th May.

10. Bosma N, Levie J (2009) The Global Entrepreneurship Monitor global report. University Desarrollo, Santiago, Chile.

11. Sasaki S (2006) Promoting Youth Employment through Entrepreneurship Education

12. Saks NT, Gaglio CM (2002) Can Opportunity Identification Be Taught? Journal of Enterprising Culture 10: 313-347.

13. Kor YS, Mahoney JT, Michael SG (2007) Resources, capabilities and entrepreneurial perceptions. Journal of Management Studies 44: 1191-1196.

14. Agada JA, Ekpa AB (2007) Entrepreneurial Development and National Reforms, J. Bus. Admin. Manage (JOBAM) 5.(1): Ede. Federal Polytechnic.

15. Morris $M$, Lewis $P$ (1995) The determinants of entrepreneurial activity. European Journal of Marketing 29: 31-48.

16. Fini R, Grimaldi R, Sobrero M (2009) Factors Fostering Academics to Start up New Ventures: an Assessment of Italian Founders' Incentives, Journal of Technology Transfer, forthcoming.

17. Liñán F (2004) Intention-Based Models of Entrepreneurship Education, Piccolla Impresa/Small Business 3: 11-35.

18. Uloka ME, Ejinkonye UB (2010) Entrepreneurial education and training for job creation. A paper presented at main Hall College of Education, EkiadolorBenin, Edo State, 12th -6th, July. 